\title{
Antioxidant Activities of Aqueous Extracts from Nine Different Rose Cultivars
}

\author{
Hamadia Khurshid ${ }^{a}$, Syed Mubashar Sabir ${ }^{a^{*}}$, Shahid Iqbal Awan ${ }^{\mathrm{b}}$, Syed Rizwan \\ AbBas $^{\mathrm{c}}$, AND MUhammad IrShad ${ }^{\mathrm{d}}$ \\ ${ }^{a}$ Department of Chemistry, University of Poonch, Rawalakot, Azad Kashmir, Pakistan \\ b Department of Plant Breeding and Molecular Genetics, University of Poonch, Rawalakot, Azad Kashmir, \\ Pakistan \\ ${ }^{\mathrm{c}}$ Department of Biological Sciences, Karakoram International University, Galgit Baltistan, Pakistan \\ ${ }^{\mathrm{d}}$ University of Kotli, Azad Jammu and Kashmir, Kotli, Pakistan \\ ${ }^{*}$ Corresponding author \\ mubashersabir@yahoo.com \\ TEL: +923455171876 \\ FAX: +9205824960007
}

Received: 3 October 2017; Published online: 18 October 2018

\begin{abstract}
Rose petals have been applied as food additives in teas, cakes and flavor extracts. The aim of this research study was to explore and reveal the antioxidant potential of aqueous extracts of rose petals belonging to nine genotypes of rose (wild as well as hybrid). The in vitro antioxidant activities of roses were studied by lipid peroxidation assay, DPPH radical scavenging assay, iron chelation assay, phosphomolybdenum reduction assay and total phenolic and flavonoid contents. The aqueous extract showed inhibition against lipid peroxidation (TBARS), induced by prooxidants $\left(10 \mu \mathrm{M} \mathrm{FeSO}_{4}\right)$ in mice liver homogenate. The free radical scavenging activities of the extracts were determined by scavenging of the DPPH radical. Extracts also showed metal chelating activities and high antioxidant activity in the phosphomolybdenum assay. The high content of phenolics and flavonoids detected in aqueous extracts may be responsible for the antioxidant activity. Amongst the different rose genotypes, screened, Rosa moschata (musk rose) was found to carry slightly higher antioxidant potential, owing to its higher phytochemical content.
\end{abstract}

Keywords: Rose; Phenolics; Radical Scavenging Activity; Iron Chelation; Lipid Peroxidation

\section{Introduction}

Reactive oxygen species (ROS) are spontaneously generated in cells during metabolism and are implicated in the aeitology of different diseases, such as heart diseases, stroke, rheumatoid arthritis, diabetes and cancer (Halliwell, Gutteridge, \& Cross, 1992). Oxidative stress is due to the decrease in natural cell antioxidant activity or due to an increased quantity of ROS in the organisms. It is well established that free radicals cause cell degeneration, especially in the liver (Shulman, Rothman, Behar, \& Hyder, 2004). Normally, intracellular molecules including mitochondrial antioxidants prevent cellular damage produced by endogenous ROS. Previously it was proposed that the progression of cancer is strongly related to oxidative stress. Thus, the validation of antioxidant effect of tested plant material is nowadays routinely supplemented with the analysis of anticancer activities (Loizzo et al., 2014; da Costa 
et al., 2015). Antioxidants are the compounds that, when added to food products, act as radical scavengers, prevent the radical chain reactions of oxidation, delay or inhibit the oxidation process and increase shelf life by retarding the process of lipid peroxidation (Young \& Woodside, 2001). Consumers are becoming more conscious of the nutritional value and safety of their food and ingredients. The preference for natural foods and food ingredients that are believed to be safer, healthier and less hazardous is increasing compared to their synthetic counterparts (Farag, Badei, Hewedi, \& Elbaroty, 1989). A number of studies have shown that the use of phenolic compounds found in tea, fruits and vegetables is associated with the low risk of these diseases (Hertog, Hollman, \& Vandeputte, 1993). Consequently, there is a growing interest in edible plants that contain antioxidants and phytochemicals as potential therapeutic agents. Foods are often contaminated with transition metal ions that may be introduced during processing. Bivalent transition metal ions catalyze the oxidative processes, resulting in the formation of hydroxyl radicals, in addition to hydroperoxide decomposition reactions, via the Fenton reaction (Wang \& Fordham, 2007). These processes can be delayed by iron chelation and deactivation.

Rose is a woody perennial of the genus Rosa and belongs to the family Rosacea. There are over a hundred species, which are widely distributed in Europe, Asia, Middle East and North America. Rose flowers vary in size, shape and colors (Raj \& Gupta, 2005). There are a number of studies from several decades ago on the chemical composition and antioxidant properties of rose in different countries of the world such as India, Chile, Iran, Turkey and Tunisia, since long (Yoshida, Wei-Sheng, \& Okuda, 1993). Rose plants are used in perfumery and in food industry. Roses are known to be a rich source of polyphenolic compounds (Yoshida et al., 1993). Rose flowers, roots and leaves have been used in Chinese medicine to treat burns, injuries and rheumatic arthritis (Fenglin, Ruili, bao, \& Liang, 2004). Rose flowers, petals and leaves have shown antioxidant activity. Some rose species also show antibacterial activities. Herbal teas of $R$. moschata studied in Chile have shown antioxidant properties (Speisky, Rocco, Carrasco,
Lissi, \& López-Alarcón, 2006). Rose hip (Rosa cannina L.) is the pseudo fruit of the rose plant which is a rich source of polyphenols and vitamin C (Fan, Pacier, \& Martirosyan, 2014). Taif rose, Ward Taifi (Rosa damascena trigintipetala Dieck), is a type of Damask rose which is considered one of the most important economic products of Taif governorate, Saudi Arabia (AbdelHameed, Bazaid, \& Salman, 2013). The genotype has a significant effect on the activity of bioactive compounds (Anttonen \& Karjalainen, 2005). Rosa damascena Mill is rich in oil and is used for ornamental purposes (Rusanov et al., 2005). Along with $R$. damascena, other rose species, such as Rosa centrifolia, Rosa gallica, Rosa alba and Rosa rugosa show a similar chemical composition and are important therapeutically (Ranganna, 1986).

Therefore, it has been found that apart from the ornamental use of rose species, rose plants (petals, leaves and rose hip) have also been used in many countries of the world for their medicinal properties, both antioxidant and antimicrobial. The literature does not quote any studies carried out related to the properties of rose plants from Pakistan. Therefore, the present study is aimed to uncover the antioxidant properties of local rose species for their possible use in food and pharmaceuticals.

\section{Materials and Methods}

\subsection{Chemicals}

Thiobarbituric acid (TBA), malonaldehydebis-dimethyl acetal (MDA), 2,2-diphenyl-1picrylhydrazyl (DPPH), quercetin, rutin, gallic acid, and phenanthroline were purchased from Sigma-Aldrich (St. Louis, MO, USA). Iron (II) sulfate was obtained from Lahore, Pakistan.

\subsection{Preparation of plant extract}

The petals of roses were collected from different areas of the district of Rawalakot Azad Kashmir during April-June, 2015 and identified by a taxonomist at the University of Poonch Rawalakot. The extracts were prepared following the method of Sabir et al. (2012). The petals of the plant 
$66 \mid$ Khurshid et al.

(25 g) were ground and soaked in boiling water $(500 \mathrm{~mL})$ for 15 minutes, allowed to cool and filtered using Whatman No. 1 filter paper. The resulting residue was further extracted twice and finally the whole extract was concentrated in a rotary evaporator $\left(50^{\circ} \mathrm{C}\right)$. Serial dilutions were prepared to obtain the desired concentration of plant for the experiments.

\section{$2.3 \quad$ Test Animals}

All animal procedures were done with the NIH Guide for the Care and Use of Laboratory Animals and were approved by the University of Poonch, Ethical Council (UPR 101). BALB/C mice (20-25g) were purchased from the National Institute of Health, Islamabad. The animals were housed in separate cages with access to water and food ad libitum, in a room with controlled temperature $\left(22 \pm 3{ }^{\circ} \mathrm{C}\right)$ and a $12 \mathrm{~h}$ light/dark cycle.

\subsection{Production of TBARS from animal tissues}

Production of TBARS was determined using a modified method (Ohkawa, Ohishi, \& Yagi, 1979). Chloroform was used to anesthetize the animals and sacrifice was by decapitation. The livers were immediately removed and placed on ice. Tissues $(1: 10, \mathrm{w} / \mathrm{v})$ were homogenized in cold $100 \mathrm{mM}$ Tris buffer $\mathrm{pH} 7.4(1: 10 \mathrm{w} / \mathrm{v})$ and centrifuged at $1,000 \mathrm{x} \mathrm{g}$ for 10 minutes. The resulting homogenates $(100 \mu \mathrm{L})$ were incubated with or without $50 \mu \mathrm{L}$ of freshly prepared oxidant (iron) and different concentrations of the extracts together with the proper volume of deionized water to give a total volume of $300 \mu \mathrm{L}$ at $37^{\circ} \mathrm{C}$ for $1 \mathrm{~h}$. The color reaction was done by adding 200 , 500 and $500 \mu \mathrm{L}$ each of the $8.1 \%$ Sodium dodecyl sulphate (SDS), acetic acid (pH 3.4) and $0.6 \%$ TBA, respectively. The reaction mixtures, including those of serial dilutions of $0.03 \mathrm{mM}$ standard MDA (1.5-9 nM), were incubated at $97{ }^{\circ} \mathrm{C}$ for $1 \mathrm{~h}$. The absorbance of tubes was read after cooling at a wavelength of $532 \mathrm{~nm}$ in a spectrophotometer.

\subsection{DPPH radical scavenging activity}

Scavenging of the stable DPPH radical (ethanolic solution of $0.25 \mathrm{mM}$ ) was assayed in vitro by the method of Hatano et al., (1988). Briefly, a $0.25 \mathrm{mM}$ solution of the $\mathrm{DPPH}$ radical $(0.5$ $\mathrm{mL}$ ) was added to extract sample solution in ethanol (1 mL) at concentrations from 25-200 $\mu \mathrm{g} / \mathrm{mL}$. The mixture was shaken vigorously and left to stand for $30 \mathrm{~min}$ in the dark, after which the absorbance was measured (Spectronic D-20; Thermo Scientific) at $517 \mathrm{~nm}$. The capacity to scavenge the DPPH radical was calculated as: $\mathrm{DPPH}$ radical scavenging $(\%)=[(\mathrm{Ao}-\mathrm{A} 1) / \mathrm{Ao})] \times$ 100

where Ao is the absorbance of the control reaction and A1 is the absorbance of the sample reaction. All determinations were carried out in triplicate.

\subsection{Antioxidant potential assay}

The total antioxidant potential of the extracts was estimated using the phosphomolybdenum reduction assay of Prieto, Pineda, and Aguilar (1999). The assay is based on the reduction of molybdenum, Mo (VI)-Mo (V) by the extract and subsequent formation of a green phosphate/Mo (V) complex at acidic $\mathrm{pH}$. The extracts $(25-200 \mu \mathrm{g} / \mathrm{mL})$ were mixed with $3 \mathrm{~mL}$ of the reagent solution ( $0.6 \mathrm{M} \mathrm{H} 2 \mathrm{SO} 4,28 \mathrm{mM}$ sodium phosphate and $4 \mathrm{mM}$ ammonium molybdate). The tubes were incubated at $95{ }^{\circ} \mathrm{C}$ for 90 mins. The mixture was cooled to room temperature and the absorbance of the solution was measured at $695 \mathrm{~nm}$.

\subsection{Metal chelating activity}

The iron chelating ability of the extract was determined using a modified method of Puntel et al., (2005). Briefly, $150 \mu \mathrm{L}$ of freshly prepared 2 $\mathrm{mM} \mathrm{FeSO} 4 \cdot 7 \mathrm{H} 2 \mathrm{O}$ was added to a reaction mixture containing $168 \mu \mathrm{L}$ of $0.1 \mathrm{M}$ Tris-HCl $(\mathrm{pH}$ 7.4), $218 \mu \mathrm{L}$ of saline, and plant extracts at concentrations of $25-200 \mu \mathrm{g} / \mathrm{mL}$. The reaction mixture was incubated for $5 \mathrm{~min}$ before addition of $13 \mu \mathrm{L}$ of $0.25 \% 1,10$-phenanthroline $(\mathrm{w} / \mathrm{v})$. The 
absorbance was subsequently measured at 510 nm using a spectrophotometer (Spectronic D-20; Thermo Scientific).

\subsection{Determination of Phenolic content}

The total phenolic content was determined by the method of Singleton, Orthofer, and LamuelaRaventós (1999). Extracts $(0.5 \mathrm{~mL})$ were added to $2.5 \mathrm{~mL}$ of $10 \%$ Folin-Ciocalteu's reagent (v/v) and $2 \mathrm{~mL}$ of $7.5 \%$ sodium carbonate. The reaction mixture was incubated at $45{ }^{\circ} \mathrm{C}$ for 40 minutes and the absorbance was measured at 765 nm using a spectrophotometer (Spectronic D-20; Thermo Scientific). Gallic acid was used as a standard phenol. The total phenolic content was expressed as $\mathrm{mg}$ of gallic acid equivalents/g of extract.

\subsection{Determination of total flavonoids}

The total flavonoid content as quercetin equivalents/g extract was based on the method of Kosalec, Pepeljnjak, Bakmaz, and VladimirKnežević (2004). Quercetin was used for preparation of a calibration curve $(0.04,0.02,0.0025$, and $0.00125 \mathrm{mg} / \mathrm{mL}$ in $80 \%(\mathrm{v} / \mathrm{v})$ ethanol). Standard solutions or extracts $(0.5 \mathrm{~mL})$ were mixed with $1.5 \mathrm{~mL}$ of $95 \%(\mathrm{v} / \mathrm{v})$ ethanol, $0.1 \mathrm{~mL}$ of $10 \%$ $(\mathrm{w} / \mathrm{v})$ aluminum chloride, $0.1 \mathrm{~mL}$ of $1 \mathrm{~mol} / \mathrm{L}$ sodium acetate, and $2.8 \mathrm{~mL}$ of water. The same volume of distilled water was substituted for $10 \%$ aluminum chloride in a blank. After incubation at room temperature for $30 \mathrm{~min}$, the absorbance of the reaction mixture was measured at 415 $\mathrm{nm}$ using a spectrophotometer (Spectronic, D-20; Thermo Scientific). The total flavonoid content was expressed as $\mathrm{mg}$ of quercetin equivalents/g of extract

\subsection{Data analysis}

The results were expressed as means \pm SD. The data were analyzed by one-way ANOVA and different group means were compared by applying Duncan's multiple range test (DMRT); $p<0.05$ was considered significant in all cases. The software package, Statistica was used for statistical analysis.

\section{Results and Discussions}

\subsection{Antilipid peroxidative properties of roses}

The present study was designed to investigate the antioxidant activity of different genotypes of roses. Lipid peroxidation in mice liver was induced with iron $(10 \mu \mathrm{M})$ and the antioxidant effect of rose extracts was determined. There was a statistically significant increase $(P<0.05)$ in the formation of TBARS in ferrous sulphate (81\%) liver homogenate compared to the basal or normal (Fig. 1a). However, treatment with roses caused a concentration dependent inhibition $(P<0.05)$ of TBARS production and brought the values close to the basal level (Fig. $1 \mathrm{a}$ and $1 \mathrm{~b}$ ). Fig. 1(a) shows that all the genotypes were effective in decreasing the level of lipid peroxidation (TBARS). However, certain genotypes like $R$. moschata, R. hybrida (tea pink), $R$. hybrida (white) showed a higher percentage of TBARS reduction compared to the control. In Fig. 1(b) different genotypes of roses such as $R$. demascena, $R$. hybrida (orange) and $R$. hybrida (pink yellow) showed a higher percentage decrease of lipid peroxidation.

Oxidative stress is now found to be associated with more than 200 diseases which include the normal aging process (Ghazanfari et al., 2006). There is a strong correlation between thiobarbituric acid-reactive substances (TBARS) as a marker of lipid peroxidation and products that reflect oxidative damage to DNA (Chen, Wu, \& Huang, 2005). It is well established that metalcatalysed generation of ROS results in an attack to DNA and proteins, but also on important cellular components which involve polyunsaturated fatty acid residues of phospholipids, which are extremely sensitive to oxidation (Shacter, 2000). Iron overload is a less frequent condition, but high contents of iron in tissues is responsible for different pathological conditions, including liver, heart diseases, cancer and neurodegenerative disorders (Milman et al., 2001). The protection of- 
$68 \mid$ Khurshid et al.

fered by the aqueous extract of roses in mice liver homogenates confirms the antioxidant activity of the extract and indicates its use in accidental toxicities resulting from the overload of iron

\subsection{DPPH radical scavenging activity of roses}

The radical scavenging activity of the extract was tested against important in vitro models of free radicals namely DPPH (Fig. 2). The role of an antioxidant is to remove free radicals. Among the genotypes $R$. moschata, $R$. hybrida (tea pink yellow), R. hybrida (tea pink), R. hybrida (white), $R$. hybrida (yellow) and $R$. demascena showed higher potential in reducing the DPPH radical (Fig. 2). Antioxidants neutralize free radicals and their negative effects. They act at different stages (prevention, interception and repair) and by different mechanisms: reducing agents by donating hydrogen, quenching singlet oxygen, acting as chelators and trapping free radicals (Devasagayam et al., 2004). DPPH ${ }^{\bullet}$ is a model of a stable lipophilic radical. A chain reaction of lipophilic radicals is started by lipid autoxidation. Antioxidants react with $\mathrm{DPPH}^{\bullet}$ and reduce the number of DPPH free radicals to the number of their available hydroxyl groups. Therefore, absorption at $517 \mathrm{~nm}$ is proportional to the amount of residual $\mathrm{DPPH}^{\bullet}$. It is visually noticeable as a discoloration of $\mathrm{DPPH}^{\bullet}$ from purple to yellow. The rose extracts also showed high radical scavenging activity which justifies their use in diseases arising from free radical attack.

\subsection{Iron chelating ability of roses}

The effect of rose extracts on iron chelation is shown in Fig. 3. Extracts exhibited strong chelating abilities in a dose-dependent manner (Fig. 3). Foods are often contaminated with transition metal ions during processing (Morgan, 1999). Bivalent metal ions speed up the oxidative processes, which results in the formation of hydroxyl radicals and hydroperoxide decomposition, via the Fenton reaction (Wang \& Fordham, 2007). These processes can be delayed by iron chelation and deactivation by the extract. The ability of the extracts to chelate iron was mea- sured as a percentage of iron chelating. Chelating agent disrupts the formation of complexes with 1,10-phenathroline and iron which leads to a decrease in color intensity. For normal health physiology, metals are necessary. On the other hand, metals can cause serious health complications. Transition metals such as iron, zinc and copper make complexes in biological systems. During complex formation there is a generation of ROS in the cells leading to metal toxicity. Metal toxicity can be treated by the chelation therapy. In this process the metal ions are chelated, and toxic and excess metal ions are removed from the system and reduce the effect. Oxidative stress caused by ferrous ions leads to many diseases such as Alzheimer's syndrome which is a neurological disorder (Ebrahimzadeh, Pourmorad, \& Bekhradnia, 2008). Many types of metal chelators are available for toxic metal chelation. But selection of ideal chelators is very difficult. Metal chelators should be specific and properly administrated (Flora \& Pachauri, 2010). Plants naturally contain phytochemicals such as phenols and flavonoids, which are responsible for the chelation of the metals and also prevent lipid peroxidation (Khan et al., 2014).

\subsection{Total antioxidant activities of roses}

The total antioxidant activity of the extract (equivalent to ascorbic acid) was found to be $50.26 \pm 2.5 \mu \mathrm{g} / \mathrm{mL}$ at a maximal concentration $(200 \mu \mathrm{g} / \mathrm{mL})$ and increased with increasing concentrations of extract (Fig. 4). R. hybrida (yellow) showed the highest antioxidant activity while, $R$. hybrida (white) showed the least antioxidant activity in the phosphomolydenum reduction assay. In this assay, which measures total antioxidant capacity, the extract demonstrated electron-donating capacity showing its ability to act as a chain terminator, transforming reactive free radical species into more stable non-reactive products (Dorman, Kosar, Kahlos, Holm, \& Hiltunen, 2003). 
Antioxidant activities of rose $\mid 69$
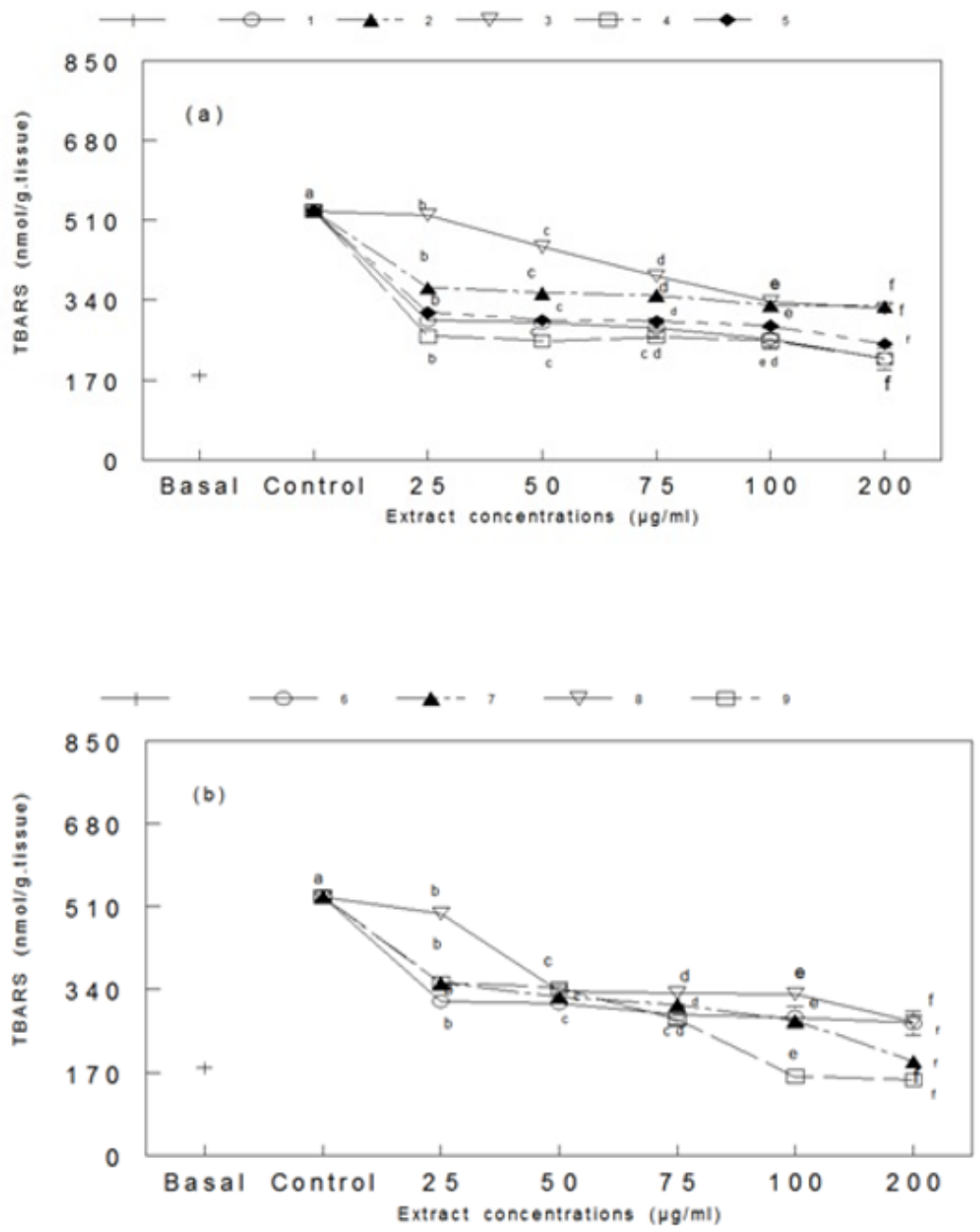

Figure 1: Inhibitory effect of Rose genotypes on lipid peroxidation induced by $10 \mu \mathrm{M} \mathrm{Fe}(\mathrm{II})$ in mice liver homogenate. (a) inhibitory effect of Rose genotypes on ferrous sulphate (Fe) induced lipid peroxidation in mice liver. $1=R$. moschata, $2=R$. hybrida (red), $3=R$. hybrida (tea pink-yellow), $4=R$. hybrida (tea pink), $5=R$. hybrida (white) (b). inhibitory effect of Rose genotypes on ferrous sulphate (Fe) induced lipid peroxidation in mice liver. $6=R$. hybrida(yellow), $7=R$. demascena, $8=R$. hybrida (orange), $9=$ $R$. hybrida (pink yellow). Values represent the means of three separate experiments in duplicate \pm SD. $p<0.05$ is significantly different from control by DMRT. Values with different letters are significantly $(p<0.05)$ different from each other by DMRT. 
$70 \mid$ Khurshid et al.

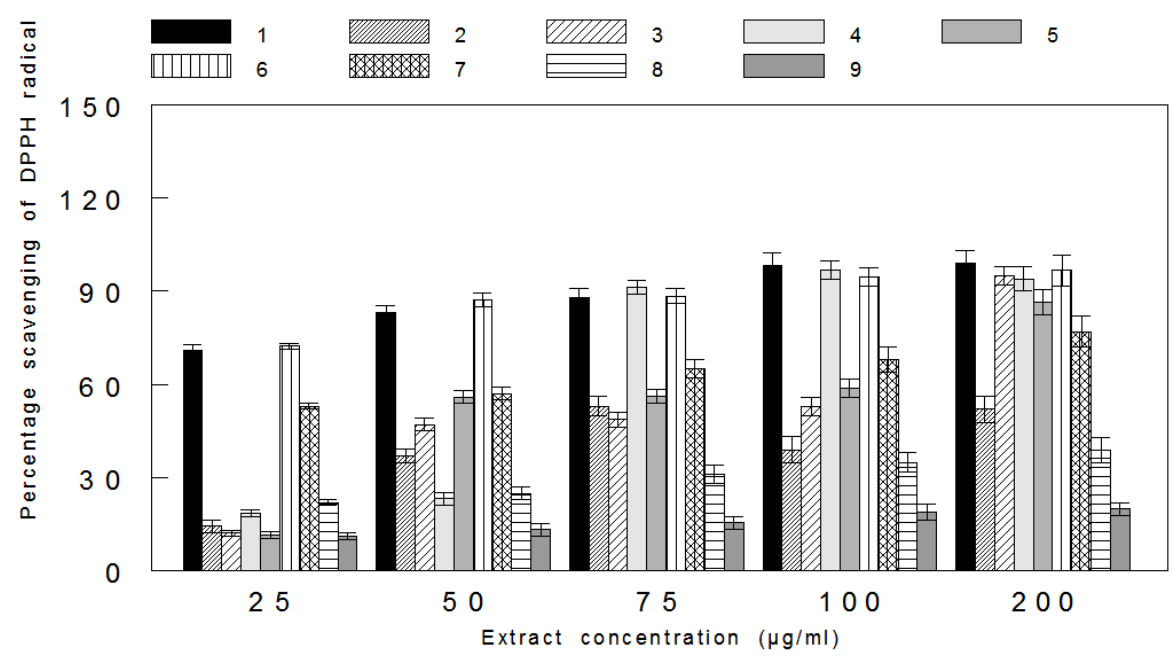

Figure 2: DPPH radical scavenging activities of Rose genotypes. $1=R$. moschata, 2= R. hybrida (red), $3=R$. hybrida (tea pink-yellow), $4=R$. hybrida (tea pink), $5=R$. hybrida (white), $6=R$. hybrida (yellow), $7=R$. demascena, $8=R$. hybrida (orange), $9=R$. hybrida (pink yellow). Values are means $\pm \mathrm{SD}$ $(n=3)$.

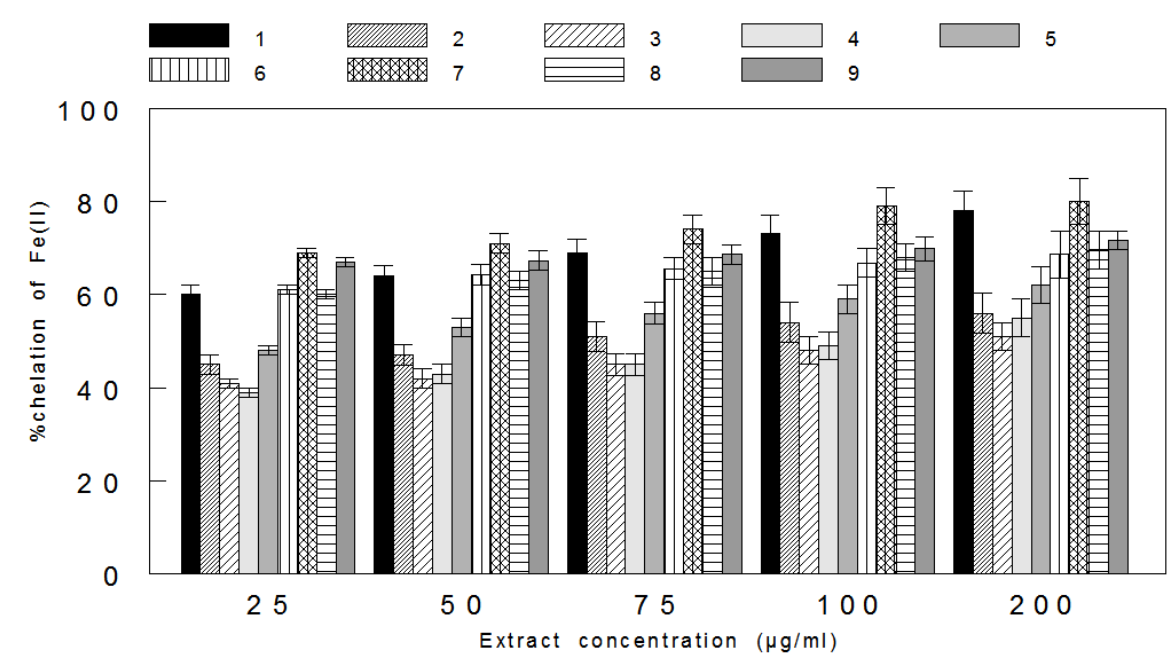

Figure 3: Iron chelating abilities of Rose genotypes. $1=R$. moschata, $2=R$. hybrida (red), $3=R$. hybrida (tea pink-yellow), $4=R$. hybrida (tea pink), $5=R$. hybrida (white), $6=R$. hybrida (yellow), $7=$ $R$. damascena, $8=R$. hybrida (orange), $9=R$. hybrida (pink yellow). Values are means $\pm \mathrm{SD}(\mathrm{n}=3)$. 


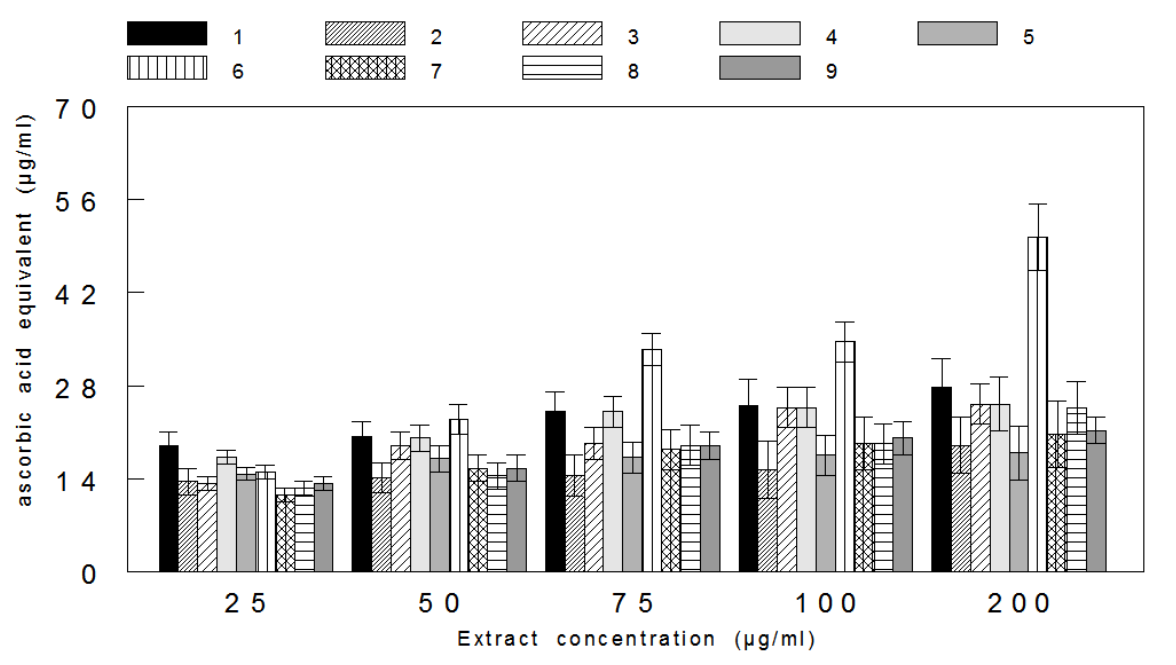

Figure 4: Total antioxidant activity of Rose genotypes as assessed by the phosphomolybdenum assay. $1=R$. moschata, $2=R$. hybrida (red), $3=R$. hybrida (tea pink-yellow), $4=R$. hybrida (tea pink), $5=$ $R$. hybrida (white), $6=R$. hybrida (yellow), $7=R$. damascena, $8=R$. hybrida (orange), $9=R$. hybrida (pink yellow). Values are means $\pm \mathrm{SD}(\mathrm{n}=3)$.

Table 1: Total phenolic ( ${ }^{*}$ GAEA mg/g) and flavonoid contents ( ${ }^{*}$ Quer $\left.{ }^{B} \mathrm{mg} / \mathrm{g}\right)$ among different genotypes of rose

\begin{tabular}{ccc}
\hline Genotype of rose & Phenolic content $(\mathrm{mg} / \mathrm{g}$ extract) & Flavonoid content (mg/g extract) \\
\hline R. moschata & $91.195 \pm 1.2^{a}$ & $8.04 \pm 0.1^{a}$ \\
R. hybrida (red) & $82.22 \pm 1.1^{b}$ & $7.56 \pm 0.12^{b}$ \\
R. hybrida (tea pink-yellow) & $77.51 \pm 0.89^{c}$ & $7.20 \pm 0.2^{c}$ \\
R. hybrida (tea pink) & $69 \pm 1^{d}$ & $6.9 \mathrm{v} 0.23^{d}$ \\
R. hybrida (white) & $67.39 \pm 1.4^{e}$ & $6.73 \pm 0.1^{e}$ \\
R. hybrida (yellow) & $67.275 \pm 0.56^{f}$ & $6.72 \pm 0.3^{e f}$ \\
R. damascena & $49.45 \pm 0.34^{g}$ & $4.95 \pm 0.1^{g}$ \\
R. hybrida (orange) & $42.09 \pm 1.1^{h}$ & $4.20 \pm 0.04^{h}$ \\
R. hybrida (pink yellow) & $39.1 \pm 0.82^{i}$ & $3.91 \pm 0.02^{i}$ \\
\hline
\end{tabular}

${ }^{*} \mathrm{GAE}^{A}$ is gallic acid equivalent, ${ }^{*} \mathrm{Quer}{ }^{B}$ is quercetin equivalent, Values with different letters are significantly $(P<0.05)$ different from each other by DMRT. 


\subsection{Total phenolic and flavonoid contents}

Table 1 shows the total phenolic and flavonoid content of roses. The phenolic content ranged between $39.1 \pm 0.82$ to $91.195 \pm 1.2 \mathrm{mg} / \mathrm{g}$ gallic acid equivalents. $R$. moschata contained the highest amount of phenolics whereas, $R$. hybrida (pink yellow) contained the least. The total flavonoid content ranged between $3.91 \pm 0.02$ to $8.04 \pm 0.1 \mathrm{mg} / \mathrm{g}$ quercetin equivalent. $R$. moschata contained the highest amount of flavonoid whereas, $R$. hybrida (pink yellow) contained the least. Plant-derived polyphenolic flavonoids are well known for exhibiting antioxidant activity through a variety of mechanisms including scavenging of ROS, inhibiting lipid peroxidation and chelating metal ions (Shahidi, 1997). The high content of phenolics and flavonoids in the extracts of plants contributes to the antioxidant activity. Joo, Kim, and Lee (2010) studied the secondary metabolites of white rose flower extract. Biological activities (antimicrobial and antioxidant properties) were determined in the extracts. Low molecular weight secondary metabolites of the white rose flower extracts were found effective in reproductive processes and showed resistance against environmental stresses and pathogens. The extracts of Rosa rugosa (white rose) flowers contained many volatile and phenolic compounds. These compounds were isolated, and their medicinal value was evaluated, in order to apply them for pharmaceutical purposes. The white rose flower extracts scavenged free radicals depending upon their concentration. Uggla, Gao, and Werlemark (2003) reported $90.5 \mathrm{mg} / \mathrm{g}$ phenolic content in rose species while Nowak and Gawlik-Dziki (2006) reported $83.4 \mathrm{mg} / \mathrm{g}$ phenolic content in rose petals which is in agreement with our studies. The total flavonoid content in methanolic rose extracts was reported to vary from 3.6-23.7 mg/g of extract (Li et al., 2014).

\section{Conclusion}

In conclusion, the aqueous extract of roses possesses anti-lipid peroxidative and free radical scavenging activities which may be associated with its high medicinal use as a functional food. The DPPH radical scavenging activities as well as the protective activities against lipid peroxidation, lead us to propose rose petal as a promising natural source of antioxidants suitable for application in the food and pharmaceutical fields and in the prevention of free radical-mediated diseases.

\section{Acknowledgements}

We are thankful to the Department of Chemistry, University of Poonch, Rawalakot, A.K. Pakistan for providing the necessary funds to carry out this research.

\section{References}

Abdel-Hameed, E.-S. S., Bazaid, S. A., \& Salman, M. S. (2013). Characterization of the phytochemical constituents of taif rose and its antioxidant and anticancer activities. Biomed Research International. doi:10.1155/2013/345465

Anttonen, M. J. \& Karjalainen, R. O. (2005). Environmental and genetic variation of phenolic compounds in red raspberry. Journal of Food Composition and Analysis, 18(8), 759-769. doi:10.1016/j.jfca.2004.11.003

Chen, H. J. C., Wu, C. F., \& Huang, J. L. (2005). Measurement of urinary excretion of 5-hydroxymethyluracil in human by $\mathrm{gc} / \mathrm{nici} / \mathrm{ms}$ : correlation with cigarette smoking, urinary tbars and etheno dna adduct. Toxicology Letters, 155(3), 403410. doi:10.1016/j.toxlet.2004.11.009

da Costa, L. S., Andreazza, N. L., Cerrea, W. R., da Silva Cunha, I. B., Tasca Gois Ruiz, A. L., de Carvalho, J. E., ... Salvador, M. J. (2015). Antiproliferative activity, antioxidant capacity and chemical composition of extracts from the leaves and stem of chresta sphaerocephala. Revista Brasileira De Farmacognosia-brazilian Journal of Pharmacognosy, 25(4), 369-374. doi:10 . 1016/j.bjp.2015.04-005 
Devasagayam, T. P. A., Tilak, J. C., Boloor, K. K., Sane, K. S., Ghaskadbi, S. S., \& Lele, R. D. (2004). Free radicals and antioxidants in human health: current status and future prospects. Journal of the Association of Physicians of India, 52(11), 794804. Retrieved from http://www.japi.org/ october2004/R-794.pdf

Dorman, H. J. D., Kosar, M., Kahlos, K., Holm, Y., \& Hiltunen, R. (2003). Antioxidant properties and composition of aqueous extracts from mentha species, hybrids, varieties, and cultivars. Journal of Agricultural and Food Chemistry, 51(16), 4563-4569. doi:10.1021/jf034108k

Ebrahimzadeh, M. A., Pourmorad, F., \& Bekhradnia, A. R. (2008). Iron chelating activity, phenol and flavonoid content of some medicinal plants from iran. African Journal of Biotechnology, 7(18), 3188-3192.

Fan, C., Pacier, C., \& Martirosyan, D. M. (2014). Rose hip (rosa canina 1): a functional food perspective. Functional Foods in Health and Disease, 4(12), 493-509.

Farag, R. S., Badei, A., Hewedi, F. M., \& Elbaroty, G. S. A. (1989). Antioxidant activity of some spice essential oils on linoleicacid oxidation in aqueous-media. Journal of the American Oil Chemists Society, 66 (6), 792-799. doi:10.1007/BF02653670

Fenglin, H., Ruili, L., bao, H., \& Liang, M. (2004). Free radical scavenging activity of extracts prepared from fresh leaves of selected chinese medicinal plants. Fitoterapia, 75(1), 14-23. doi:10.1016/j. fitote. 2003.07.003

Flora, S. J. S. \& Pachauri, V. (2010). Chelation in metal intoxication. International Journal of Environmental Research and Public Health, 7(7), 2745-2788. doi:10.3390/ ijerph7072745

Ghazanfari, G., Minaie, B., Yasa, N., Nakhai, L. A., Mohammadirad, A., Nikfar, S., ... Abdollahi, M. (2006). Biochemical and histopathological evidences for beneficial effects of satureja khuzestanica jamzad essential oil on the mouse model of inflammatory bowel diseases. Toxicology Mecha- nisms and Methods, 16(7), 365-372. doi:10. 1080/15376520600620125

Halliwell, B., Gutteridge, J. M. C., \& Cross, C. E. (1992). Free-radicals, antioxidants, and human-disease - where are we now. Journal of Laboratory and Clinical Medicine, $119(6), 598-620$.

Hertog, M. G. L., Hollman, P. C. H., \& Vandeputte, B. (1993). Content of potentially anticarcinogenic flavonoids of tea infusions, wines, and fruit juices. Journal of Agricultural and Food Chemistry, 41(8), 12421246. doi:10.1021/jf00032a015

Joo, S. S., Kim, Y.-B., \& Lee, D. I. (2010). Antimicrobial and antioxidant properties of secondary metabolites from white rose flower. Plant Pathology Journal, 26(1), 5762. doi:10.5423/PPJ.2010.26.1.057

Khan, A., Sabir, S. M., Nazar, H., Hamid, A., Usmanghani, K., \& Ali, H. (2014). Antioxidant activities and inhibitory effects of dietary plants against sodium nitroprusside induced lipid peroxidation in the mouse brain and liver. Food Science and Biotechnology, 23(4), 1305-1311. doi:10 . $1007 /$ s10068-014-0179-0

Kosalec, I., Pepeljnjak, S., Bakmaz, M., \& Vladimir-Knežević, S. (2004). Quantitative analysis of the flavonoids in raw propolis from northern croatia. Acta Pharmaceutica, 54(1), 65-72. Retrieved from http : / / widgets . ebscohost . com / prod / customerspecific / ns000290 / authentication / index . php ? url $=$ https $\%$ $3 \mathrm{a} \% 2 \mathrm{f} \%$ 2fsearch. ebscohost.com $\% 2$ flogin. aspx $\%$ 3fdirect $\%$ 3dtrue $\%$ 26AuthType $\%$ 3 dip $\%$ 2ccookie $\%$ 2cshib $\%$ 2cuid $\% 26 \mathrm{db} \%$ 3dedselc \% 26AN \% 3dedselc . 2 - 52 . 0 $1942520353 \%$ 26lang \% 3dpt - br \% 26site \% 3deds-live\%26scope\%3dsite

Li, L., Ham, H., Sung, J., Kim, I., Jeongand, H., \& Lee, J. (2014). Antioxidant activities of methanolic extracts from four different rose cultivars. Journal of Food and Nutrition Research, 2(2), 69-73. doi:10.12691/ jfnr-2-2-2

Loizzo, M. R., Rashed, K., Said, A., Bonesi, M., Menichini, F., \& Tundis, R. (2014). Antiproliferative and antioxidant properties of alhagi maurorum boiss (leguminosae) 
aerial parts. Industrial Crops and Products, 53, 289-295. doi:10.1016/j.indcrop. 2013. 12.049

Milman, N., Pedersen, P., Steig, T. A., Byg, K. E., Graudal, N., \& Fenger, K. (2001). Clinically overt hereditary hemochromatosis in denmark 1948-1985: epidemiology, factors of significance for long-term survival, and causes of death in 179 patients. Annals of Hematology, 80(12), 737-744. doi:10.1007/s002770100371

Morgan, J. N. (1999). Effects of processing on heavy metal content of foods. In L. S. Jackson, M. G. Knize, \& J. N. Morgan (Eds.), Impact of processing on food safety (pp. 195-211). Boston, MA: Springer US. doi:10.1007/978-1-4615-4853-9_13

Nowak, R. \& Gawlik-Dziki, U. (2006). Polyphenols of rosa l. leaves extracts and their radical scavenging activity. Zeitschrift für Naturforschung C, 62(1-2), 32-38. doi:10. 1515/znc-2007-1-206

Ohkawa, H., Ohishi, N., \& Yagi, K. (1979). Assay for lipid peroxides in animal-tissues by thiobarbituric acid reaction. Analytical Biochemistry, 95 (2), 351-358. doi:10.1016/ 0003-2697(79)90738-3

Prieto, P., Pineda, M., \& Aguilar, M. (1999). Spectrophotometric quantitation of antioxidant capacity through the formation of a phosphomolybdenum complex: specific application to the determination of vitamin e. Analytical Biochemistry, 269(2), 337-341. Retrieved from http://widgets.ebscohost. com / prod / customerspecific / ns000290 / authentication / index . php ? url = https \% 3a $\% 2 \mathrm{f} \%$ 2fsearch. ebscohost.com $\% 2$ flogin. aspx $\%$ 3fdirect $\%$ 3dtrue $\%$ 26AuthType $\%$ 3 dip $\%$ 2ccookie $\%$ 2cshib $\%$ 2cuid $\% 26 \mathrm{db} \%$ 3dedselc \% 26AN \% 3dedselc . 2 - 52 . 0 $0344348886 \%$ 26lang \% 3dpt - br \% 26site \% 3deds-live\%26scope\%3dsite

Raj, D. \& Gupta, P. K. (2005). Standardizing dehydration technology for ornamental herbaceous plants from outer himalayas. Journal of Ornamental Horticulture, 8(1), 53-55.

Ranganna, S. (1986). Handbook of analysis and quality control for fruit and vegetable products. Tata McGraw-Hill Education.
Rusanov, K., Kovacheva, N., Vosman, B., Zhang, L., Rajapakse, S., \& Atanassov, I., A .and Atanassov. (2005). Microsatellite analysis of rosa damascena mill. accessions reveals genetic similarity between genotypes used for rose oil production and old damask rose varieties. Theoretical and Applied Genetics, 111 (4), 804-809. doi:10.1007/s00122-0052066-9

Sabir, S. M., Ahmad, S. D., Hamid, A., Khan, M. Q., Athayde, M. L., Santos, D. B., ... Rocha, J. B. T. (2012). Antioxidant and hepatoprotective activity of ethanolic extract of leaves of solidago microglossa containing polyphenolic compounds. Food Chemistry, 131 (3), 741-747. doi:10.1016/j. foodchem.2011.09.026

Shacter, E. (2000). Protein oxidative damage. In Singlet oxygen, uv-a, and ozone (Vol. 319, pp. 428-436). Methods in Enzymology.

Shahidi, F. (1997). Natural antioxidants, chemistry, health effects and applications. In F. Shahidi (Ed.), (Chap. Natural antioxidants: An overview, pp. 1-11). The American Oil Chemists Society.

Shulman, R. G., Rothman, D. L., Behar, K. L., \& Hyder, F. (2004). Energetic basis of brain activity: implications for neuroimaging. Trends in Neurosciences, 27(8), 489495. doi:10.1016/j.tins.2004.06.005

Singleton, V. L., Orthofer, R., \& LamuelaRaventós, R. M. (1999). [14] analysis of total phenols and other oxidation substrates and antioxidants by means of folinciocalteu reagent. In Oxidants and antioxidants part a (Vol. 299, pp. 152-178). Methods in Enzymology. Academic Press. doi:10.1016/S0076-6879(99)99017-1

Speisky, H., Rocco, C., Carrasco, C., Lissi, E. A., \& López-Alarcón, C. (2006). Antioxidant screening of medicinal herbal teas. Phytotherapy Research, 20(6), 462. Retrieved from http: / / widgets. ebscohost. com / prod / customerspecific / ns000290 / authentication/index.php?url=https $\% 3 \mathrm{a} \%$ 2f\% 2 fsearch.ebscohost.com $\% 2$ flogin.aspx $\%$ 3fdirect $\%$ 3dtrue $\%$ 26AuthType $\% 3$ dip \% 2ccookie $\%$ 2cshib $\%$ 2cuid $\% 26 \mathrm{db} \% 3$ dedb $\%$ 26AN \% 3d64211910 \% 26lang \% 3dpt - br \% 26 site $\% 3$ deds-live $\% 26$ scope $\% 3$ dsite 
Antioxidant activities of rose $\mid 75$

Uggla, M., Gao, X., \& Werlemark, G. (2003). Variation among and within dogrose taxa (rosa sect. caninae) in fruit weight, percentages of fruit flesh and dry matter, and vitamin c content. Acta Agriculturae Scandinavica, Section B-Plant Soil Science, 53(3), 147-155.

Wang, S. Y. \& Fordham, I. M. (2007). Differences in chemical composition and antioxidant capacity among different genotypes of autumn olive (elaeagnus umbellate thunb.) Food Technology and Biotechnology, 45(4), 402-409.

Yoshida, T., Wei-Sheng, F., \& Okuda, T. (1993). Two polyphenol glycosides and tannins from rosa cymosa. Phytochemistry, 32(4), 1033-1036. Retrieved from http://widgets. ebscohost . com / prod / customerspecific / ns000290 / authentication / index . php ? $\mathrm{url}=\mathrm{https} \% 3 \mathrm{a} \% 2 \mathrm{f} \% 2$ fsearch. ebscohost . com $\% 2$ flogin . aspx $\%$ 3fdirect $\% 3$ dtrue $\%$ 26 AuthType $\% 3$ dip $\%$ 2ccookie $\% 2$ cshib \% 2cuid \% 26db\% 3dedselc \% 26AN\% 3dedselc. 2- 52 . 0 - 0008479119\% 26lang \% 3dpt - br \% 26site\%3deds-live\%26scope\%3dsite

Young, I. S. \& Woodside, J. V. (2001). Antioxidants in health and disease. Journal of Clinical Pathology, 54 (3), 176-186. doi:10. 1136/jcp.54.3.176 